\title{
IDENTIFIKASI KOHOR DAN DUGAAN LAJU PERTUMBUHAN IKAN PELAGIS KECIL DI LAUT JAWA
}

\author{
Suwarso") dan Tuti Hariati")
}

\begin{abstract}
ABSTRAK
Ikan pelagis kecil merupakan hasil tangkapan utama di Laut Jawa, terutama dari perikanan purse seine; enam jenis paling dominan yaitu: layang (Decapterus russelli), deles (D. macrosoma), banyar (Rastrelliger kanagurta), bentong (Selar crumenophthalmus), siro (Ambligaster sirm), dan tembang (Sardinella gibbosa). Penentuan kohor dan dugaan laju pertumbuhan dari ke enam jenis tersebut dilakukan berdasarkan data frekuensi panjang yang terkumpul selama Mei 1991 sampai Desember 1993 dari hasil tangkapan purse seine. Hasil menunjukkan pada dasarnya hanya terdapat satu kohor utama (major cohort) yang muncul setiap tahun di samping cohort minor (jumlahnya tidak banyak) yang muncul sekitar musim barat (Desember-Februari). Bulan Mei-Agustus diketahui sebagai awal rekrut dengan panjang rata-rata kelompok antara 8-10 cm FL. Kohor minor dari ikan siro dan tembang (Clupeidae) tidak ditemukan, sedangkan ikan bentong memiliki pola kohor yang berbeda. Kurva perubahan biomassa umumnya berbentuk poligon di mana individu ikan muda dominan dalam populasi.
\end{abstract}

\section{ABSTRACT: Cohort identification and growth estimation of small pelagic fishes of the Java Sea. By: Suwarso and Tuti Hariati}

Cohort analysis and growth rate estimation of the six main small pelagic fishes of the Java Sea, notably scad (Decapterus russelli), round scad (D. macrosoma), Indian mackerel (Rastrelliger kanagurta), big-eye scad (Selar crumenophthalmus), spotted sardine (Ambligaster sirm), and goldstripe sardine (Sardinella gibbosa) were carried out based on the length frequency data collected from purse seine fishery during May 1991 to December 1993. The result showed that the existence of one major cohort was identified each year with fewer minor cohorts that found especially during west monsoon. In general, the main recruitment of the stocks occurred in May to August with average individual size of 8-10 cm FL. The minor cohort of two species of Clupeidae (notably spotted and goldstripe sardines) was not found; while bigeye scad was found to have a different cohort pattern. Polygon curve of the biomass is usually observed, and is dominated by the young fishes of the population

\section{KEYWORDS: $\quad$ cohort analysis, growth rate, small pelagic fish, Java Sea}

\section{PENDAHULUAN}

Hasil tangkapan ikan pelagis kecil di Laut Jawa dengan pukat cincin mencapai $40 \%$ dari total ikan pelagis yang didaratkan (Potier \& Sadhotomo, 1995a). Dari sekitar 30 species yang tertangkap selama tahun 1992, tujuh di antaranya memberikan kontribusi sebesar $90 \%$ dari seluruh hasil tangkapan yang didaratkan, $60 \%$ dari keseluruhan berupa ikan layang (Decapterus russelli dan $D$. macrosoma). Jenis lainnya yang tertangkap cukup banyak adalah banyar (Rastrelliger kanagurta) 18\%, siro (Amblygaster sirm) $7,4 \%$, bentong (Selar crumenophthalmus) $7 \%$, dan tembang (Sardinella gibbosa) $7 \%$ (Potier \& Sadhotomo, 1995b). Total hasil tangkapan tiap species bervariasi baik secara tahunan maupun musiman.

Berdasarkan pada perhitungan rata-rata ukuran panjang ikan yang tertangkap telah diketahui ada stratifikasi ukuran menurut tempat, namun semakin ke arah timur ukuran ikan semakin besar (Sadhotomo \& Potier, 1995b). Dalam penerapan "Model Analitik" diperlukan parameter pertumbuhan yang lebih akurat karena berfungsi sebagai elemen dasar dalam analisis dinamika populasi. Dalam makalah ini dibahas mengenai 'kohor' atau broods, yaitu sekelompok individu ikan dari jenis yang sama yang berasal dari kelahiran (pemijahan) yang sama (Sparre et al., 1989), dari ke enam jenis utama dan dugaan laju pertumbuhannya berdasarkan data distribusi frekuensi panjang ikan yang didaratkan. Mengingat perubahan-perubahan dinamis pada stok ikan pelagis, selain berguna sebagai dasar dalam studi umur, hasil penelitian ini juga bermanfaat sebagai data pembanding dalam pengkajian stok pada umumnya. Dugaan 'kohor' untuk dua jenis ikan layang di perairan yang sama telah dikemukakan oleh Widodo (1988a, 1988b) dan Widodo (1989); banyar oleh Nurhakim (1993) serta layang, siro dan bentong oleh Suwarso et al. (1995).

\footnotetext{
Peneliti pada Balai Riset Perikanan Laut, Jakarta
} 


\section{BAHAN DAN METODE}

\section{Data Frekuensi Panjang}

Data yang digunakan berupa serial data frekuensi panjang bulanan periode Mei 1991 sampai dengan Desember 1993 yang dikumpulkan oleh "Java Sea Pelagic Fishery Assessment Project" (Sadhotomo \& Potier, 1992, 1993, 1994). Data frekuensi panjang diperoleh melalui pengukuran terhadap hasil tangkapan pukat cincin yang mendarat di Pekalongan dan Juwana (Jawa Tengah). Pengambilan contoh ikan dilakukan di atas kapal setiap hari secara acak berlapis menurut daerah penangkapan yang sesuai dengan prosedur sampling yang telah diuraikan oleh Potier \& Sadhotomo (1991) dan Boely et al. (1990). Data kemudian dikelompokkan menurut waktu (bulan) dan daerah penangkapan dalam selang kelas panjang $1 \mathrm{~cm}$.

\section{Analisis Data}

Dalam analisis digunakan data yang telah disesuaikan terlebih dahulu terhadap hasil tangkapan melalui penggandaan dengan suatu nilai faktor pengganda (raising factor). Penggandaan dilaksanakan dalam dua tahap, pertama terhadap hasil tangkapan suatu jenis ikan pada kapal contoh, kedua terhadap total hasil tangkapan jenis tersebut pada suatu daerah penangkapan pada bulan sampling (Sadhotomo \& Potier, 1992). Berat ikan contoh dihitung dengan menggunakan persamaan hubungan panjang berat yang telah diperoleh (Suwarso, 1993). Selanjutnya data yang berasal dari daerah penangkapan di Laut Jawa dan sekitarnya, yaitu di pantai Utara Indramayu, Utara Tegal dan Pekalongan, perairan sekitar Kep. Karimunjawa, $\mathrm{P}$ Bawean, P. Masalembo, Kep. Matasirih, dan perairan Lumu-lumu di Selat Makasar, digabungkan menjadi satu unit data frekuensi panjang untuk dianalisis. Penggabungan tersebut didasarkan pada hasil penelitian struktur genetik populasi bahwa populasi ikan di perairan-perairan tersebut diduga merupakan unit stok yang sama (Arnaud, 1996).

Pendugaan kohor dilakukan dengan cara merunut kelompok-kelompok ukuran panjang (komponen kohor) yang muncul setiap bulan. Setiap komponen kohor diasumsikan sebagai sekelompok individu ikan yang memiliki umur/ukuran yang hampir sama (Sparre et al., 1989) sehingga ukuran panjangnya diasumsikan menyebar menurut distribusi normal. Pemisahan suatu unit data frekuensi panjang (biasanya merupakan mixture length-frequency dan polymodal) ke dalam komponen-komponennya (kelompok ukuran panjang) yang masing-masing tersebar normal dilakukan menurut cara
Bhattacharya (Bhattacharya, 1967; Sparre et al., 1989). Cara ini memberikan nilai-nilai statistik seperti rata-rata panjang (mean-length), simpangan baku (standard deviasi) dan jumlah individu dari setiap kelompok ukuran.

Dugaan laju pertumbuhan dilakukan menurut plot Gulland and Holt, plot Von Bertalanffy dan Elefan 1 (Ricker, 1975; Sparre et al., 1989). Proses perhitungan dilakukan dengan menggunakan perangkat lunak FiSAT (Gayanilo, 1995; Gayanilo et al., 1993)

\section{HASIL. DAN BAHASAN}

\section{Identifikasi Kohor}

Kohor diperoleh dengan memisahkan data frekuensi panjang ke dalam kelompok-kelompok dengan panjang rata-rata tertentu serta simpangan bakunya. Kelompok-kelompok tersebut diasumsikan berdistribusi normal. Dari hasil analisis diperoleh antara 1 sampai 3 komponen kohor setiap bulan yang bervariasi menurut waktu dan spesies. Gambar 1 memperlihatkan diagram scatter dari komponen-komponen kohor yang dapat diidentifikasi masing-masing pada ikan layang, banyar, bentong, siro, dan tembang.

Dari Gambar 1 tersebut terlihat adanya suatu pergeseran nilai rata-rata panjang (modal progression) dari bulan ke bulan mulai dari kelompok ukuran terkecil sampai dengan ukuran maksimum. Dengan merunut komponenkomponen kohor yang muncul setiap bulan terlihat kecenderungan munculnya hanya satu kohor utama (major cohort) setiap tahun: kohor A adalah kohor tahun 1991, kohor B adalah kohor tahun 1992, dan kohor C adalah kohor tahun 1993. Kemunculan satu kohor utama setiap tahun ini tampak jelas terutama pada spesies oseanik seperti $D$. macrosoma, $A$. sirm, dan $R$. kanagurta, sedangkan pada selar bentong kurang begitu jelas walaupun kecenderungan itu ada. Pola yang kurang jelas pada ikan ini disebabkan munculnya beberapa kohor minor pada musim tertentu (sekitar musim barat) yang diduga berhubungan dengan sifat reproduktif spesies tersebut.

Didasarkan pada komponen kohor yang ditemukan tersebut, terlihat pola pertumbuhan kohor umumnya berbentuk kurva asimptotik di mana setelah mencapai ukuran panjang tertentu (ukuran maksimum) kurva tersebut biasanya mendatar sesuai dengan sifat pertumbuhan ikan Rata-rata panjang dari kelompok ukuran maksimum yang dicapai beserta simpangan bakunya tertera pada Tabel 1; nilai-nilai tersebut merupakan perkiraan panjang asimptotik $\left(L_{\infty}\right)$ yang dicapai oleh tiap species 

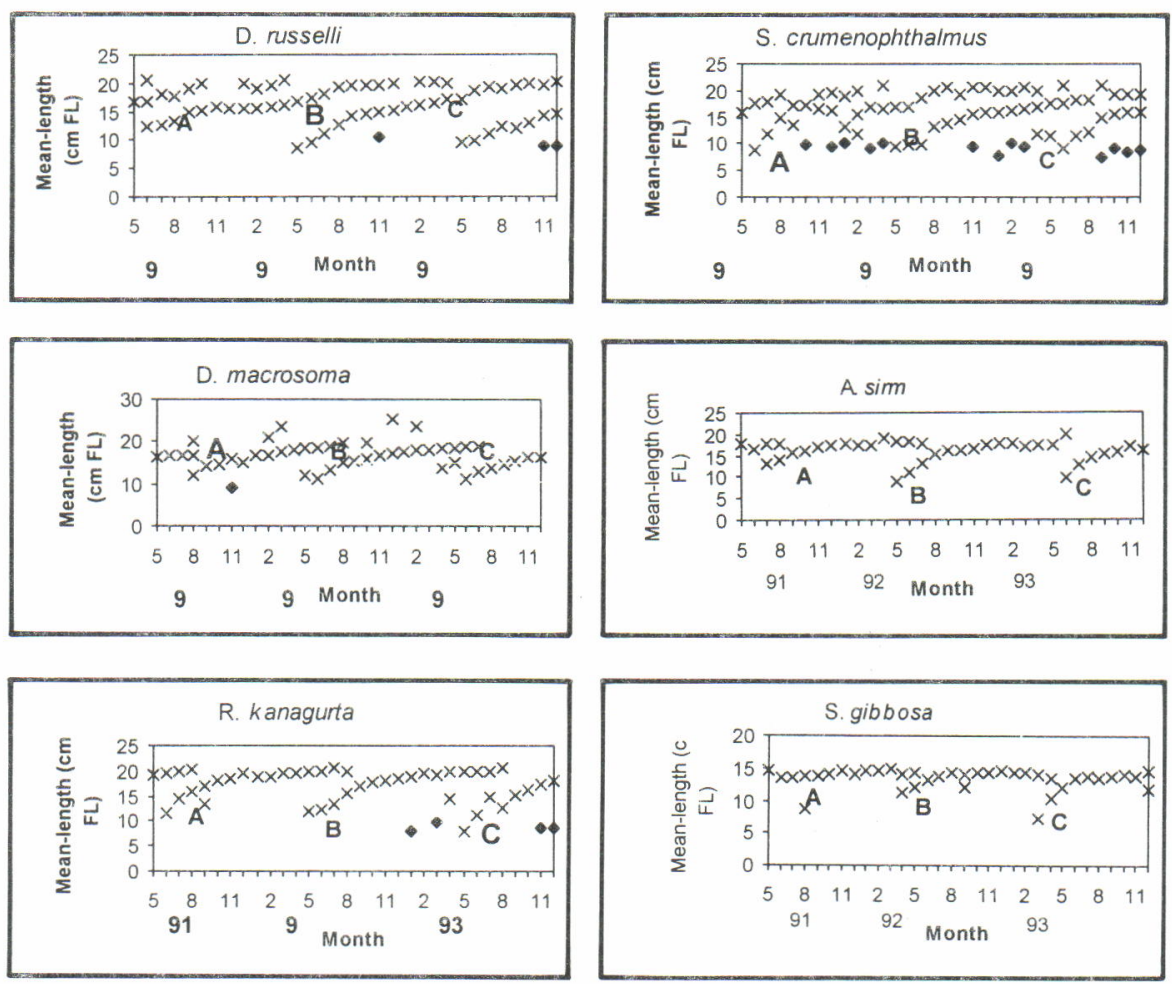

Keterangan/Remark:

Skater titik adalah kohor minor/Point scatters are the minor cohorts

Gambar 1. Diagram skater dari komponen-komponen kohor (panjang rata-rata dalam $\mathrm{cm}$ ).

Figure 1. Scatter diagrams of the cohort components (mean length in $\mathrm{cm}$ ).

Tabel 1. Rata-rata ukuran dari kelompok ukuran panjang terbesar dari enam jenis ikan pelagis kecil yang dominan di Laut Jawa

Table 1. Mean-length of the maximum length groups of six small pelagic species of the Java Sea

\begin{tabular}{lcc}
\hline \multicolumn{1}{c}{$\begin{array}{c}\text { Jenis } \\
\text { (Species) }\end{array}$} & \multicolumn{2}{c}{$\begin{array}{c}\text { Kohor } \\
\text { (Cohort) }\end{array}$} \\
\cline { 2 - 3 } D. russelli & A (tahun 1991-1992/year 1991-1992) $\mathbf{B}$ (tahun 1992-1993/year 1991-1992) \\
D. macrosoma & $20,2(0,94)$ & $20,2(1,06)$ \\
R. kanagurta & $19,9(0,64)$ & $18,8(1,37)$ \\
S. crumenophthalmus & $20,6(0,85)$ & $20,5(0,94)$ \\
A. sirm & $21,1(1.56)$ & $19,3(1,26)$ \\
S. gibbosa & $18,9(1,13)$ & $19,8(1,21)$ \\
\hline Keterangan : : Angka dalam kurung merupakan simpangan baku dari nilai rata-rata ukuran panjang & $14,5(0,81)$. \\
Remark & The value in parentheses indicate standard deviation of average length
\end{tabular}

Kelompok ukuran terkecil merupakan awal rekrutmen pada perikanan pukat cincin yang sedang berjalan. Pada ke enam spesies yang diamati rekruitmen ini berlangsung antara bulan Mei-Agustus setiap tahun (Gambar 1). Rata-rata panjang dari kelompok ukuran terkecil ini bervariasi untuk tiap spesies, yaitu antara 8,5-12,2 $\mathrm{cm}$ untuk ikan layang, $11,0-12,2 \mathrm{~cm}$ untuk deles, $8,0-11,6 \mathrm{~cm}$ untuk banyar, $8,7-9,4 \mathrm{~cm}$ untuk bentong, 9,0-13,1 cm untuk siro, dan 7,2-13,4 cm untuk ternbang. Menurut Sadhotomo \& Potier (1995) kelompok ikan-ikan muda ini umumnya tertangkap di perairan yang lebih dekat ke pantai, yaitu di perairan sebelah utara Indramayu, utara Tegal, utara Pekalongan, dan di sekitar Kepulauan Karimun Jawa.

Di samping kohor utama tersebut di atas dapat diidentifikasi kelompok ikan-ikan muda (ukuran rata-rata antara 8-10 $\mathrm{cm} \mathrm{FL)} \mathrm{yang} \mathrm{muncul} \mathrm{sekitar}$ 
musim barat terutama pada ke empat jenis utama, yaitu ikan layang (D. russelli dan D. macrosoma.), banyar dan bentong. Sedangkan pada kedua jenis Clupeidae ( $A$. sirm dan S. gibbosa) pola demikian tidak terlihat. Kelompok ini jumlahnya relatif tidak banyak (disebut kohor minor), yaitu kira-kira antara $1-4 \%$ untuk kedua spesies ikan layang dan 11\% untuk ikan banyar. Namun pada ikan bentong kohor minor ini jumlahnya sangat bervariasi, antara $1-58 \%$. Pola kemunculan kohor pada ikan-ikan tersebut diperkirakan berhubungan erat dengan sifat biologi (pola pemijahan) dan toleransinya pada habitat.

\section{Jumlah Relatif}

Didasarkan pada data jumlah individu relatif (dalam \%) dari setiap kelompok ukuran yang diperoleh dari hasil pemisahan "mixtured lengthfrequency data" dapat disusun kurva perubahan biomassa dari setiap kohor seperti ditunjukkan pada Gambar 2.
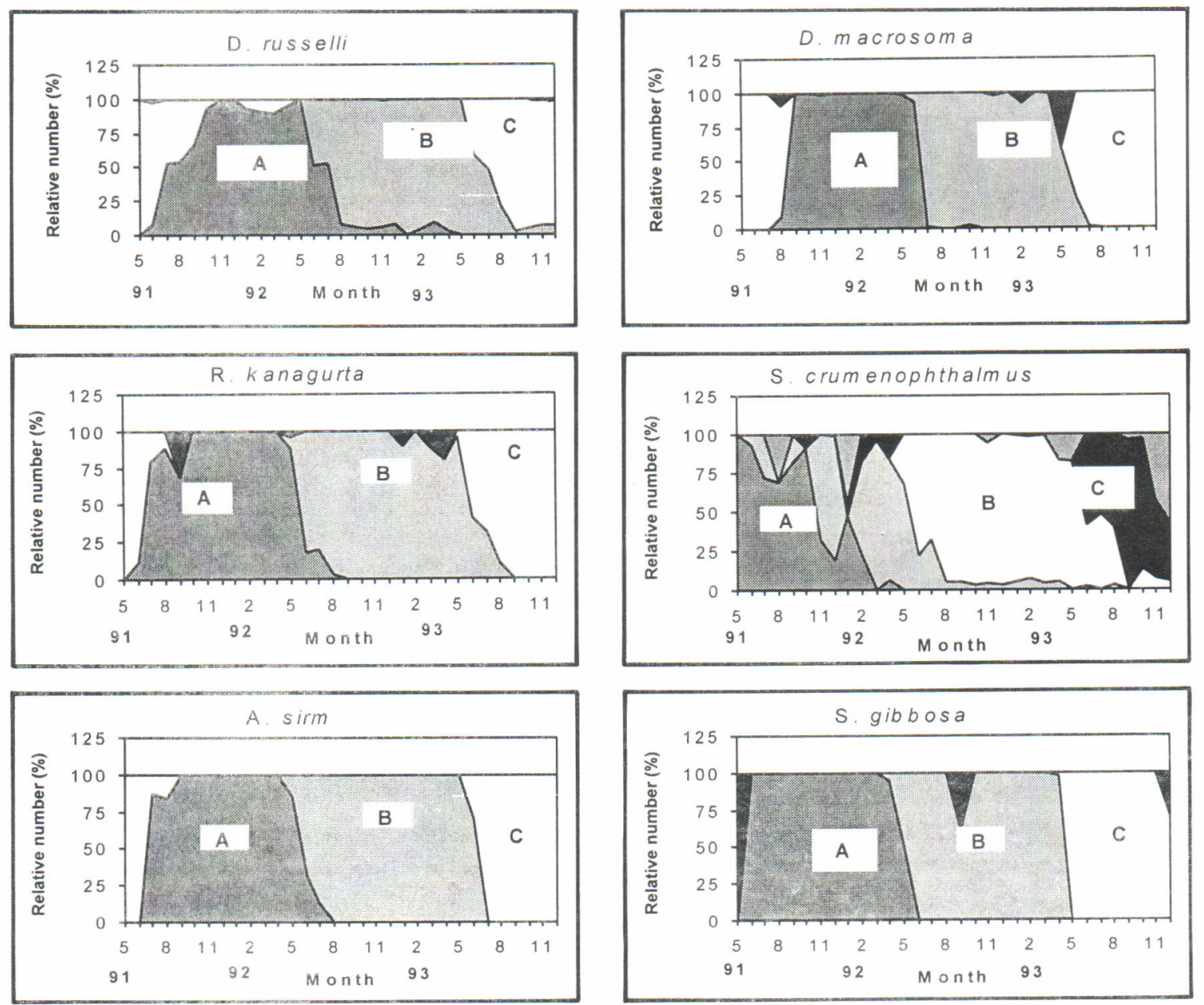

Gambar 2. Kurva perubahan biomassa dari kohor ikan pelagis kecil di Laut Jawa.

Figure 2. Curve of the biomassa of a cohort of small pelagic fishes of the Java Sea.

Secara umum terlihat bahwa bentuk kurva perubahan biomass dari setiap spesies berupa kurva poligon yang sejalan dengan pertumbuhan ukuran/umur ikan. Pada awal rekrutmen, jumlah ikan dari kelompok terkecil (ukuran minimum,) relatif sedikit, yaitu antara 1-8\% untuk layang, 2$9 \%$ untuk deles, $2-4 \%$ untuk banyar, $7-32 \%$ untuk bentong, $15-30 \%$ untuk siro, dan $2-5 \%$ untuk tembang; kemudian sejalan dengan pertumbuhan ukuran komponen-komponen kohor berikutnya muncul semakin banyak $(>75 \%)$, yaitu pada ukuran rata-rata antara 12,8-17,2 cm untuk layang 13,2-18,6 cm untuk deles, 11,3-20,0 untuk banyar, 9,8-17,5 untuk bentong, 10,9-18,3 untuk siro, dan $12,1-14,8$ untuk tembang. Mendekati ukuran maksimum (ikan-ikan ukuran besar) jumlah individu dari tiap komponen kohor semakin sedikit. Pada bulan-bulan yang merupakan puncak hasil tangkapan, yaitu September-November (Potier \& Sadhotomo, 1995), populasi ikan pelagis didominasi oleh kelompok ikan dengan ukuran panjang rata-rata sebagai berikut: layang 12,1- 
$15,9 \mathrm{~cm}$, deles $14,3-16,7 \mathrm{~cm}$, banyar $15,3-18,4 \mathrm{~cm}$, bentong $13,9-19,2 \mathrm{~cm}$, siro $15,3-17,0 \mathrm{~cm}$, dan tembang $13,8-14,6 \mathrm{~cm}$.

Menurut Atmaja et al. (1995) kematangan seksual yang pertama (length-at-first mature, $I_{m}$ ) dari jenis-jenis tersebut tercapai pada ukuran sebagai berikut: layang $21,0 \mathrm{~cm}$, deles $20,7 \mathrm{~cm}$, banyar $21,4 \mathrm{~cm}$, bentong $18,7 \mathrm{~cm}$, siro $18,6 \mathrm{~cm}$, dan tembang $14,7 \mathrm{~cm}$; sedangkan rata-rata panjang saat memijah pertama (length-at-first spawning, $I_{s}$ ) jenis-jenis tersebut tercapai pada ukuran sebagai berikut: layang $20,5 \mathrm{~cm}$, deles 20,1 $\mathrm{cm}$, banyar $21,0 \mathrm{~cm}$, bentong $18,0 \mathrm{~cm}$, siro 19,0 $\mathrm{cm}$, dan tembang $12,5-13,4 \mathrm{~cm}$ ). Selisih ukuran antara $I_{m}$ dan ukuran saat memijah pertama tersebut dimungkinkan karena jumlah dan sebaran data yang berbeda. Nilai $I_{m}$ diperoleh dari sejumlah besar contoh ikan betina dengan tingkat kematangan gonad III (maturing), IV (mature), dan spent; sedang $I_{s}$ diperoleh dari contoh riil gonad dalam kondisi matang gonad dan spent yang jumlahnya sedikit. Individu ikan berukuran lebih besar seringkali ditemukan dalam kondisi pematangan (TKG III). Sehubungan dengan hal tersebut dapat diduga:

a) Ikan-ikan yang tertangkap oleh perikanan pukat cincin didominasi $(>75 \%)$ oleh individu ikan muda yang belum matang seksual (immature dan maturing), artinya masih belum mencapai ukuran length-at-first mature maupun length-at-first spawning. Hal ini mengindikasikan bahwa area penangkapan utama dari perikanan pukat cincin di Laut Jawa merupakan daerah untuk mencari makan (feeding ground) bagi ikan-ikan tersebut.

b) Diperkirakan ikan-ikan ukuran besar yang tertangkap dalam jumlah relatif kecil karena keluar dari daerah penangkapan untuk menuju ke daerah pemijahan (spawning ground) sehingga tidak tertangkap pukat cincin. Kelompok tersebut kemungkinan sedang dalam tingkat kematangan akhir (late maturing) dan atau telah matang telur (mature). Gejala ini nampak pada ikan bentong betina matang telur yang diperkirakan hanya $2 \%$ tertangkap pukat cincin (Suwarso \& Sadhotomo, 1995).

Dari ke enam spesies yang diamati kecenderungan rekrutmen secara serentak dalam waktu yang hampir bersamaan, yaitu antara bulan Mei-Agustus, dapat dijumpai pada lima spesies ikan, yaitu layang, deles, banyar, siro, dan tembang. Pola demikian tidak tampak pada selar bentong. Puncak rekrutmen pada waktu tersebut diduga berasal dari puncak pemijahan yang terjadi beberapa bulan sebelumnya. Melalui pengamatan visual dan mikroskopis terhadap gonad contoh menunjukkan bahwa musim pemijahan diduga berlangsung selama beberapa bulan setiap tahun tergantung species. Ikan layang memijah antara bulan Mei-Desember; deles antara Mei-Nopember; siro antara Februari-Juni; banyar antara MaretNopember; dan bentong antara April-Desember (Atmaja et al., 1995). Puncak pemijahan ikan layang dan bentong diperkirakan terjadi antara bulan September-Desember.

\section{Dugaan Laju Pertumbuhan ( $L_{\infty}$ dan $\left.K\right)$}

Nilai rata-rata ukuran yang diperoleh dari hasil pemisahan data frekuensi panjang ke dalam kelompok-kelompok ukuran digunakan dalam analisis untuk memperoleh parameter pertumbuhan $\left(L_{\infty}\right.$ dan $K$ ) melalui analisis growth increment dengan plot Gulland \& Holt, sedangkan Elefan 1 diterapkan untuk mendapatkan parameter pertumbuhan dari data frekuensi panjang; hasilnya ditunjukkan pada Tabel 2. Analisis tersebut terutama ditujukan terhadap kohor utama yang muncul setiap tahun (Gambar 1).

Pada Tabel 2 dapat dilihat bahwa $L_{\infty}$ ( $L$-infinity) atau panjang asimptotik yang diperoleh dari plot Gulland \& Holt lebih rendah dari nilai $L_{\infty}$ yang diperoleh dari analisis dengan Elefan 1 karena data yang digunakan dalam analisis berbeda. Data masukan yang digunakan dalam analisis growth increment merupakan nilai rata-rata ukuran (meanlength) dari setiap kelompok ukuran sehingga nilai $L_{\infty}$ yang diperoleh juga merupakan panjang maksimum dari sekelompok ukuran ikan yang berasal dari kohor yang bersangkutan, sedangkan $L$ s. yang diperoleh dari Elefan 1 merupakan panjang maksimum ikan contoh dari kohor yang diasumsikan muncul setiap tahun pada waktu yang sama. Perbedaan nilai parameter pertumbuhan yang diperoleh dari analisis growth increment dan Elefan 1 disebabkan data masukan yang digunakan masing-masing berbeda; analisis growth increment menggunakan data masukan yang berupa ukuran rata-rata dari kelompok ikan, sedangkan analisis Elefan 1 menggunakan data sebaran frekuensi panjang dengan titik awal (starting point), biasanya merupakan ukuran ikan dari komponen kohor terkecil) yang dipakai berbeda. Jadi walaupun data frekuensi panjang yang digunakan dalam analisis selama tiga tahun namun parameter pertumbuhan yang diperoleh akan diasumsikan sama setiap tahun tergantung dari titik awal yang dipakai. Sedangkan variasi nilai parameter pertumbuhan antara dua kohor pada tahun yang sama kemungkinan bersumber pada jumlah dan ukuran ikan contoh yang digunakan.

Seperti telah disebutkan di atas bahwa puncak recrutmen dari kohor utama setiap tahun diduga 
Tabel 2. Parameter pertumbuhan $\left(L_{\text {in }}\right.$ dan $K$ ) dari enam jenis ikan pelagis kecil di Laut Jawa berdasarkan Plot Gulland \& Holt dan analisis Elefan 1

Table 2. Estimation of growth parameters $\left(L_{x}\right.$ and $\left.K\right)$ of six small pelagic fishes of the Java Sea based on the Gulland \& Holt Plot and Elefan 1 analysis

\begin{tabular}{lcccccc}
\hline \multirow{2}{*}{$\begin{array}{c}\text { Spesies } \\
\text { Species }\end{array}$} & Kohor & \multicolumn{3}{c}{ Plot Gulland \& Holt } & \multicolumn{3}{c}{ Elefan 1 } \\
\cline { 3 - 7 } & Cohort & $\mathrm{L}_{\infty}$ & $\mathrm{K}$ & $\mathrm{r}^{2}$ & $\mathrm{~L}_{\infty}$ & $\mathrm{K}$ \\
\hline D. russelli & $\mathrm{A}(91 / 92)$ & 24.3 & 0.8 & 0.168 & 27.3 & 0.5 \\
D. macrosoma & $\mathrm{B}(92 / 93)$ & 22.6 & 1.2 & 0.354 & 27.8 & 0.7 \\
& $\mathrm{~A}$ & 22.7 & 1.6 & 0.137 & 26.7 & 0.8 \\
R. kanagurta & $\mathrm{B}$ & 19.2 & 3.0 & 0.800 & 27.2 & 0.7 \\
& $\mathrm{~A}$ & 20.5 & 3.9 & 0.759 & 27.8 & 0.9 \\
S. crumenophthalmus & $\mathrm{B}$ & 20.4 & 3.6 & 0.928 & 27.3 & 1.1 \\
& $\mathrm{~A}$ & 21.6 & 2.0 & 0.380 & 27.0 & 1.7 \\
A. sirm & $\mathrm{B}$ & 19.4 & 1.9 & 0.272 & 26.7 & 0.7 \\
& $\mathrm{~A}$ & 19.8 & 2.3 & 0.268 & 21.0 & 1.8 \\
S. gibbosa & $\mathrm{B}$ & 20.4 & 2.4 & 0.308 & 21.0 & 1.8 \\
& $\mathrm{~B}$ & 14.7 & 4.3 & 0.644 & 22.0 & 0.7 \\
\hline
\end{tabular}

berasal dari puncak musim pemijahan yang berlangsung beberapa bulan sebelumnya; pada kenyataannya sangat sulit untuk menentukan umur dari setiap kelompok ukuran/umur (komponen kohor) sehubungan dengan rentang pemijahan yang cukup lama, yaitu sekitar 5-9 bulan tergantung species (Atmaja, 1988). Hal ini mempengaruhi nilai parameter pertumbuhan yang diperoleh melalui analisis growth increment (plot Gulland dan Holt).

Cara lain penentuan umur individu ikan atau kelompok ikan dengan hasil yang lebih teliti dan akurat dapat dilakukan melalui struktur mikro otolith (batu telinga) seperti dikemukakan oleh Campana \& Neilson (1985); Gjosaeter et al. (1984); Panella (1974). Walaupun untuk ikan-ikan tropik tumbuh secara harian (daily increment) sehingga menghasilkan lingkaran pertumbuhan (increment) yang cukup banyak tetapi dengan menggunakan peralatan yang memadai lingkaran pertumbuhan tersebut dapat dideteksi. Studi awal tentang umur dan pertumbuhan terhadap jenisjenis tersebut telah dilakukan oleh Java Sea Pelagic Fishery Assessment Project bersama dengan LASAA (Laboratoire de Sclẻrochronologie des Animaux Aquatiques), IFREMER, Brest, Perancis.

Dengan mempertimbangkan konsep dasar dalam analisis data frekuensi panjang dengan menggunakan Elefan 1 untuk mendapatkan parameter pertumbuhan, analisis secara terpisah dapat dilakukan sehingga parameter yang diperoleh akan dapat dibandingkan dengan parameter yang diperoleh dari analisis growth increment (plot Gulland \& Holt). Karena parameter pertumbuhan yang diperoleh dari analisis data frekuensi panjang tersebut bersifat subjektif pengukuran melalui mikrostruktur otolith disarankan untuk mendapatkan nilai-nilai yang lebih teliti dan akurat.

Menurut Atmaja (1999) analisis terhadap data frekuensi panjang periode 1996-1998 diperoleh bahwa secara umum ukuran rata-rata ikan yang tertangkap pukat cincin di perairan ini relatif sama dengan penelitian tahun-tahun sebelumnya (Sadhotomo \& Potier, 1995; Widodo, 1988 Dwiponggo et al 1986). Dari hal tersebut diduga parameter pertumbuhan juga relatif konstan, karena pola pertumbuhan (growth pattern) biasanya konstan meskipun dengan skala yang berbeda menurut waktu.

\section{KESIMPULAN}

Dari uraian tersebut di atas dapat disimpulkan sebagai berikut:

1. Setiap tahun di Laut Jawa hanya muncul satu kohor utama ikan pelagis kecil, awal rekrutmen pada perikanan pukat cincin terjadi antara bulan Mei-Agustus setiap tahun

2. Kurva perubahan biomassa umumnya berupa kurva poligon sesuai dengan pertumbuhan ikan. Kurva tersebut didominasi oleh ikan-ikan muda (ukuran sekitar $10-20 \mathrm{~cm}$ tergantung species) yang belum matang seksual.

3. Dari kedua metode yang diterapkan memberikan parameter pertumbuhan $\left(L_{\text {s) }}\right.$ dan $K)$ yang berbeda; nilai $L_{\infty}$ yang diperoleh dari plot Gulland \& Holt merupakan nilai rata-rata kelompok, sedang $L_{\infty}$ yang diperoleh dari Elefan 1 bersifat ukuran maksimum yang dicapai. 


\section{DAFTAR PUSTAKA}

Arnaud, S. 1996. Le chinchard Decapterus macrosoma, poisson pélagique de la mèr de Java, un exemple de etructure génétique en milieu marin. Mémoire de DEA, Université Montpellier 2, Montpellier.

Atmaja S.B. 1988. Estimation of growth and mortality of round scad (Decapterus macrosoma) in the Java Sea, Indonesia. In: Venema S.C, J.M. Christensen and D. Pauly (eds.), Contribution to Tropical Fisheries Biology. FAO, Fish. Rep., 389: 324--345.

Atmaja, S.B. 1999. Variasi geografis hasil tangkapan ikan layang (Decapterus spp.) di perairan bagian selatan Paparan Sunda. Jurnal Penelitian Perikanan Indonesia V (3): 62--71.

Atmaja S.B., B. Sadhotomo, \& Suwarso. 1995. Reproduction of the main small pelagic species. In: Potier, M. and S. Nurhakim (eds.), BIODYNEX: Biology, Dynamics, Exploitation of the Small Pelagic Fishes in the Java Sea. AARD/ORSTOM: 69--84.

Bhattacharya, C.G. 1967. A simple method of resolution of a distribution into Gaussian components. Biometrics.23: 115--135.

Boely, T., M. Potier, \& S. Nurhakim. 1990. Study on the big purse seiners fishery in the Java Sea. VI: Sampling Procedure. J. Mar. Res. Fish. Ins., 56, 1--12.

Campana, S.E. \& Neilson. 1985. Microstructure of fish otolith. Canadian Journal of Fisheries Aquatic Science 42: 1014--1032 (Reviews).

Dwiponggo, A., T. Hariati, S.B. Atmaja, M.L. Palomares \& D. Pauly. 1986. Growth, mortality and recruitment of commercially important fishes and penaeid shrimps in Indonesia Waters. ICLARM Tech. Rep., 17: 91 hal.

Gayanilo, Jr.F.C. 1995. FiSAT \& stock assessment In: Potier, M. and S. Nurhakim (eds.), BIODYNEX: Biology, Dynamics, Exploitation of the Small Pelagic Fishes in the Java Sea. AARD/ORSTOM, Hal: 257--260.

Gayanilo, Jr. F.C., P. Sparre \& D. Pauly. 1993. The FiSAT user's guide. ICLARM, FAO, Rome.

Gjosaeter, J., P. Dayaratne, O.A. Bergstad, H. Gjosaeter, M.I. Sousa \& I.M. Beck. 1984. Ageing tropical fish by growth rings in the otoliths. FAO Fisheries Circular 776: 54 hal.
Nurhakim, S. 1993. Biologie et dynamique du banyar Rastrelliger kanagurta (Teleosteen Scombridae) dans la pecherie des grands senneurs en mer de Java. These. Univ. Bretagne Occidentale, Brest, France: 106 hal.

Pannella, G. 1974. Otolith growth patterns aid in age determination in temperate and tropical fishes. In: Bagenal, T.B. (ed), Ageing of Fish, Proceedings of an International Symposium. Unwin Brothers Limited, England. Hal: 28--39.

Potier, M. \& B. Sadhotomo. 1991. Sampling training. ALA/INS/87/17, Sci. Tech. Doc., 4, 29.

Potier, M. \& B. Sadhotomo. 1995. Seiners fisheries in Indonesia. In: Potier, $\mathrm{M}$. and $\mathrm{S}$. Nurhakim (eds.), BIODYNEX: Biology, Dynamics, Exploitation of the Small Pelagic Fishes in the Java Sea. AARD/ORSTOM, Hal: 49--66.

Potier, M. \& B. Sadhotomo. 1995b. Exploitation of the large and medium seiners fisheries in the Java Sea. In: Potier, M. and S. Nurhakim (eds.), BIODYNEX: Biology, Dynamics, Exploitation of the Small Pelagic Fishes in the Java Sea. AARD/ORSTOM, Hal: 195--214.

Ricker, W.E. 1975. Computation and interpretation of biological statistics of fish population. Bull. Fish. Res. Board Can., (191): 382 hal.

Sadhotomo, B. \& M. Potier. 1995. Exploratory scheme for the recruitment and migration of the main pelagic species of the Java Sea. In: Potier, M. \& S. Nurhakim (eds.), BIODYNEX: Biology, Dynamics, Exploitation of the Small Pelagic Fishes in the Java Sea. AARDORSTOM, Hal: 155--168.

Sadhotomo, B. \& M. Potier. 1992. Length composition of the main pelagic species caught by the seiners of the Java Sea. Year 19901991. ALAINS./87/17. Science and Tech. Doc. No.14.

Sadhotomo, B. \& M. Potier. 1993. Length composition of the main pelagic species caught by the seiners of the Java Sea. Year 19911992. ALA/INS./87/17. Science and Tech. Doc. No. 15: 171 hal.

Sadhotomo, B. \& M. Potier. 1994. Length composition of the main pelagic species caught by the seiners of the Java Sea. Java Sea Pelagic Fishery Assessment Project. Sci. Tech. Doc., 20 hat.

Sparre, P., E. Ursin \& S.C. Venema. 1989. Introduksi pengkajian stok ikan tropis. Buku I: 
Manual. FAO - Puslitbang Perikanan - Badan Litbang Pertanian. 438 hal.

Suwarso. 1993. Length-weight relationships of the main pelagic fishes of the Java Sea. Java Sea Pelagic Fishery Assessment Project. Sci. Tech. Doc., 10.

Suwarso \& B. Sadhotomo. 1995. Studi biologi reproduksi dan komponen kohor ikan bentong (Selar crumenophthalmus Bloch) fam. Carangidae di Laut Jawa. Disampaikan dalam Seminar Ilmiah dan Kongres Nasional Biologi XI. Bogor, 24-27 Januari. 1995. 15 hal.

Suwarso, B. Sadhotomo, \& S.B. Atmadja. 1995. Growth parameters of the main small pelagic species. In Biodynex - Biology, Dynamics, Exploitation of the Small Pelagic Fishes in the
Java Sea. M. Potier \& S. Nurhakim Eds. AARDORSTOM-EEC. Hal: 85--96.

Widodo, J. 1988a. Population parameters of "ikan layang", scad mackerel (Decapterus spp.) (Pisces: Carangidae) in the Java Sea. J. Mar. Res. Fish. Inst., 46. Hal: 11--44.

Widodo, J. 1988b. Population biology of russell's scad (Decapterus russelli) in the Java Sea, Indonesia. In: Venema S.C, J.M. Christensen and D. Pauly (eds.), Contribution to tropical fisheries biology. FAO, Fish. Rep., 389. Hal: 308--323.

Widodo, J. 1989. Preliminary assessment on effects of changes in size limit and fishery intensity on the small pelagic multispecies in the Java Sea. J. Mar. Fish. Res. Ins. No. 51: 67--78. 